\title{
Educational Leadership
}

December 1997/January 1998 | Volume 55 | Number 4

Reaching for Equity Pages 23-26

\section{Two Languages Are Better Than One}

\section{Dual language programs help native and nonnative speakers of English speak two languages proficiently-and they do so in cost-effective ways that lead to high academic achievement for all students.}

\section{Wayne P. Thomas and Virginia P. Collier}

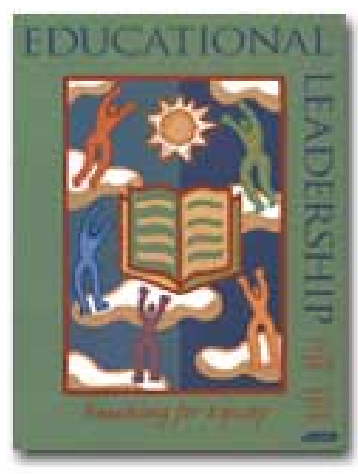

December 1997/

January 1998

Among the underachieving youth in U.S. schools, students with no proficiency in English must overcome enormous equity gaps, school achievement tests in English show. Over the past three decades, schools have developed a wide range of programs to serve these English learners. After much experimentation, U.S. schools now have clear achievement data that point to the most powerful models of effective schooling for English learners. What is astounding is that these same programs are also dynamic models for school reform for all students.

Imagine how the 21st century will look. Our world will surely be in constant change, for we are facing this pattern now. The predictions of the near future also depict an interconnected world, with global travel and instant international communications. Right now, many U.S. businesses seek employees proficient in both English and another language. Students who graduate with monocultural perspectives will not be prepared to contribute to their societies, for cross-cultural contact is at an all-time high in human history as population mobility continues throughout the world (Cummins in Ovando and Collier, in press). Thus, majority and minority language students together must prepare for a constantly changing world.

\section{Tapping the Power of Linguistic Diversity}

For more than three decades, as we have struggled to develop effective models for schooling English learners, we have mostly considered the choices available to us from a deficit perspective. That is, we have often viewed English learners as a "problem" for our schools (oh, no-they don't know English), and so we "remediate" by sending them to a specialist to be "fixed." In the remedial program, English learners receive less access to the standard gradelevel curriculum. The achievement and equity gap increases as native English speakers forge ahead while English learners make less progress. Thus, underachieving groups continue to underachieve in the next generation. Unfortunately, the two most common types of U.S. school services provided for English learners-English as a Second Language (ESL) pullout and 
transitional bilingual education-are remedial in nature. Participating students and teachers suffer often from the social consequences of this perception.

But when the focus of any special school program is on academic enrichment for all students, the school community perceives that program positively, and students become academically successful and deeply engaged in the learning process. Thus, enrichment programs for English learners are extremely effective when they are intellectually challenging and use students' linguistic and cultural experiences as a resource for interdisciplinary, discovery learning (Chiang 1994, Ovando and Collier in press, Thomas and Collier 1997). Further, educators who use the enrichment models that were initially developed for English learners are beginning to see the power of these models for all students.

\section{A History of Bilingual Enrichment}

These innovative enrichment models are called by varying names-dual language, bilingual immersion, two-way bilingual, and developmental bilingual education. We recommend these models as forms of mainstream education through two languages that will benefit all students. Let's examine the history of their development and some basic characteristics of these models. Initially, the first two 20th-century experiments with bilingual education in the United States and Canada in the early 1960 s came about as a result of parental pressure. Both of these experiments were enrichment models. In Canada, English-speaking parents who wanted their children to develop deep proficiency in both French and English initiated what became known as immersion education. Immersion is a commitment to bilingual schooling throughout grades $\mathrm{K}-12$ in which students are instructed 90 percent of the school day during kindergarten and grade 1 in the minority language chosen for the program, and 10 percent of the day in the majority language (English). The hands-on nature of academic work in the early grades is a natural vehicle for proficiency development of the minority language.

Immersion programs emphasize the less dominant language more than English in the first years, because the minority language is less supported by the broader society, and academic uses of the language are less easily acquired outside school. Gradually, with each subsequent grade, the program provides more instruction in the majority language until children learn the curriculum equally through both languages by grade 4 or 5 . By grade 6 , students have generally developed deep academic proficiency in both languages, and they can work on math, science, social studies, and language arts at or above grade level in either language. From the 1960 s to the 1990s, immersion bilingual schooling has grown immensely popular in Canada and has achieved high rates of success with majority and minority students, students of middle- and low-income families, as well as students with learning disabilities (Cummins and Swain 1986, Genesee 1987).

About the same time that the first immersion program started in Canada, Cubans arriving in Miami, Florida, initiated the first U.S. experiment with two-way bilingual education in 1963 . The term two-way refers to two language groups acquiring the curriculum through each other's languages; one-way bilingual education refers to one language group receiving schooling through two languages (Stern 1963). Intent on overthrowing Fidel Castro and returning to their 
country, the Cuban arrivals established private bilingual schools to develop their children's English and maintain their Spanish. The public schools, losing significant enrollment, chose to develop bilingual classes to attract students back. As English-speaking parents enrolled their children in the classes, two-way, integrated bilingual schooling emerged as a new program model in the United States. These classes provided a half day of the grade-level curriculum in Spanish and a half day in English, now known as the 50-50 model of two-way.

Over time, these two experiments have expanded to many states in the United States as school communities recognize the benefits for all students. The immersion model, originally developed in Canada for majority language speakers, has become known as the 90-10 two-way model in the United States because during the first two years both language groups receive 90 percent of the instruction through the minority language.

\section{Students as Peer Language Models}

Key to the success of all two-way programs is the fact that both language groups stay together throughout the school day, serving as peer tutors for each other. Peer models stimulate natural language acquisition for both groups because they keep the level of interaction cognitively complex (Panfil 1995). Research has consistently demonstrated that academic achievement is very high for all groups of participants compared to control groups who receive schooling only through English. This holds true for students of low socioeconomic status, as well as AfricanAmerican students and language-minority students, with those in the 90-10 model achieving even higher than those in the 50-50 model (Lindholm 1990, Lindholm and Aclan 1991, Thomas and Collier 1997).

\section{The Role of Careful Planning}

What are other essential characteristics of this school reform? An important principle is clear curricular separation of the two languages of instruction. To maintain a continuous cognitive challenge, teachers do not repeat or translate lessons in the second language, but reinforce concepts taught in one language across the two languages in a spiraling curriculum. Teachers alternate the language of instruction by theme or subject area, by time of day, by day of the week, or by the week. If two teachers are teaming, each teacher represents one language. When two teachers share and exchange two classes, this is a cost-effective, mainstream model that adds no additional teachers to a school system's budget. In contrast, ESL pullout is the most costly of all program models for English learners because extra ESL resource teachers must be added to the mainstream staff (Crawford 1997).

Successful two-way bilingual education includes

- a minimum of six years of bilingual instruction;

- focus on the core academic curriculum rather than on a watered-down version;

- quality language arts instruction in both languages;

- separation of the two languages for instruction;

- use of the non-English language for at least 50 percent of the instructional time and as 
much as 90 percent in the early grades;

- an additive bilingual environment that has full support of school administrators;

- a balanced ratio of students who speak each language (for example, 50:50 or 60:40, preferably not to go below 70:30);

- promotion of positive interdependence among peers and between teachers and students;

- high-quality instructional personnel; and

- active parent-school partnerships (Lindholm 1990).

Demographics influence the feasibility of two-way programs, because the students in each language group serve as peer teachers for each other. A natural choice for many U.S. schools is a Spanish-English two-way program, because Spanish speakers are most often the largest language group. In the 204 two-way bilingual schools identified in the United States in a 1997 survey, other languages of instruction in addition to Spanish include, in order of frequency, Korean, French, Cantonese, Navajo, Japanese, Arabic, Portuguese, Russian, and Mandarin Chinese (Montone et al. 1997).

\section{Closing the Equity Gap Through Bilingual Enrichment}

What makes these programs work? To answer this question, let's look at the students who are initially the lowest achievers on tests in English. Most school policymakers commonly assume that students need only a couple of years to learn a second language. But while these students make dramatic progress in English development in the first two years, English language learners are competing with a moving target, the native English speaker, when tested in English.

The average native English speaker typically gains 10 months of academic growth in one 10month school year in English development because first language acquisition is a natural work in progress throughout the school years, not completed until young adulthood. Although some score higher and some lower, on average they also make a year's progress in a year's time in mathematics, science, and social studies. Thus students not yet proficient in English initially score three or more years below grade level on the tests in English because they cannot yet demonstrate in their second language all that they actually know. These students must outgain the native speaker by making one and one-half years progress on the academic tests in their second language for each of six successive school years (a total of nine years progress in six years) to reach the typical performance level of the constantly advancing native English speaker.

When students do academic work in their primary language for more than two to three years (the typical support time in a transitional bilingual program), they are able to demonstrate with each succeeding year that they are making more gains than the native English speaker-and closing the gap in achievement as measured by tests in English across the curriculum. After five to six years of enrichment bilingual schooling, former English learners (now proficient in English) are able to demonstrate their deep knowledge on the academic tests in English across the curriculum, as well as in their native language, achieving on or above grade level (Thomas 
and Collier 1997).

\section{Bridging the Gap to a Better Tomorrow}

Why is such progress for English learners important for our schools? Language-minority students are predicted to account for about 40 percent of the school-age population by the 2030s (Berliner and Biddle 1995). It is in our pragmatic self-interest to ensure their success as young adults, for they will be key to a robust economy to pay retirement and medical benefits for today's working adults. We must close the equity gap by providing enrichment schooling for all. For native English speakers as well as language-minority students, the enrichment bilingual classes appear to provide a constant stimulus and intellectual challenge similar to that of a gifted and talented class. The research evidence is overwhelmingly clear that proficient bilinguals outperform monolinguals on school tests (Collier 1995). Crossing cultural, social class, and language boundaries, students in a bilingual class develop multiple ways of solving human problems and approach ecological and social science issues from a cross-national perspective. These learners acquire deep academic proficiency in two languages, which becomes a valuable resource in adult professional life. And they learn to value each other's knowledge and life experiences-leading to meaningful respect and collaboration that lasts a lifetime.

\section{References}

Berliner, D.C., and B.J. Biddle. (1995). The Manufactured Crisis: Myths, Fraud, and the Attack on America's Public Schools. Reading, Mass.: Addison-Wesley.

Chiang, R.A. (1994). "Recognizing Strengths and Needs of All Bilingual Learners:

A Bilingual/Multicultural Perspective." NABE News 17, 4: 11, 22-23.

Collier, V.P. (1995). Promoting Academic Success for ESL Students:

Understanding Second Language Acquisition for School. Elizabeth: New Jersey

Teachers of English to Speakers of Other Languages-Bilingual Educators.

Crawford, J. (1997). Best Evidence: Research Foundations of the Bilingual

Education Act. Washington, D.C.: National Clearinghouse for Bilingual Education.

Cummins, J., and M. Swain. (1986). Bilingualism in Education. New York: Longman.

Genesee, F. (1987). Learning Through Two Languages: Studies of Immersion and Bilingual Education. Cambridge, Mass.: Newbury House.

Lindholm, K.J. (1990). "Bilingual Immersion Education: Criteria for Program Development." In Bilingual Education: Issues and Strategies, edited by A.M. Padilla, H.H. Fairchild, and C.M. Valadez. Newbury Park, Calif.: Sage.

Lindholm, K.J., and Z. Aclan. (1991). "Bilingual Proficiency as a Bridge to Academic Achievement: Results from Bilingual/Immersion Programs." Journal of Education 173: 99-113. 
Montone, C., Christian, D., and A. Whitcher. (1997). Directory of Two-way Bilingual Programs in the United States. Rev. ed. Washington, D.C.: Center for Applied Linguistics.

Ovando, C.J., and V.P. Collier. (in press). Bilingual and ESL Classrooms: Teaching in Multicultural Contexts. 2nd ed. New York: McGraw-Hill (available in Nov. 1997).

Panfil, K. (1995). "Learning from One Another: A Collaborative Study of a Twoway Bilingual Program by Insiders with Multiple Perspectives." Dissertation

Abstracts International 56-10A, 3859. (University Microfilms No. AAI96-06004).

Stern, H.H., ed. (1963). Foreign Languages in Primary Education: The Teaching of Foreign or Second Languages to Younger Children. Hamburg, Germany:

International Studies in Education, UNESCO Institute for Education.

Thomas, W.P., and V.P. Collier. (1997). School Effectiveness for Language

Minority Students. Washington, D.C.: National Clearinghouse for Bilingual

Education.

Wayne P. Thomas is Professor of Research and Evaluation Methods, and Virginia P. Collier is Professor of Bilingual/Multicultural/ESL Education, Graduate School of Education, George Mason University, MS\#4B3, Fairfax, VA 22030-4444 (e-mail: wthomas@gmu.edu; vcollier@gmu.edu). The authors are researchers with the Center for Research on Education, Diversity, and Excellence (CREDE), funded by the Office of Educational Research and Improvement, U.S. Department of Education.

Copyright (C) 1997 by ASCD

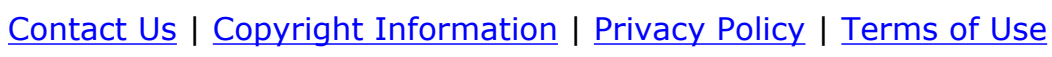

(C) 2009 ASCD 